\title{
Biotechs await single European financial market
}

The European Commission (EC; Brussels) launched, on October 27, an in-depth assessment of the state of integration of European markets. This exercise will assess the effectiveness of new policy measures gathered under the Financial Services Action Plan (FSAP), which is designed to establish similar regulations for all current markets with the aim of creating a single financial market across Europe by 2005. But before the biotech industry can fully benefit from such a harmonized financial system, the sector must mature and investors must become less parochial.

The FSAP includes a new Transparency Directive that, if passed in 2004, would force companies listed on European exchanges to issue financial reports on a quarterly basis. By increasing transparency in financial reporting, the directive aims to boost a company's visibility to cross-border investors and thus increase the liquidity of a company's shares. But "it is to be questioned if quality of accounting and increase of transparency is sufficient to enhance crossborder investments," says Peter Heinrich, CEO of oncology company Medigen (Martinsried, Germany) and president of the industry group European Emerging Biopharmaceutical Enterprises (Brussels).

Indeed, in spite of the EC's harmonization efforts, investors could still remain focused on home markets. "Homogeneous rules [across Europe] can only help but I doubt it is going to be enough. All markets are very 'local,"' says Philippe Archinard, CEO of therapeutics and diagnostics company Innogenetics (Ghent, Belgium). Archinard says he experienced the homebound nature of investors in Europe when Innogenetics listed on Euronext (Brussels), which is a joint exchange among Brussels, Amsterdam and Paris; the company's shares have attracted little interest from investors outside Belgium because of low trading volume and inherent low visibility, says Archinard.

"What we need goes much beyond harmonization [of market regulations] and is in fact a real pan-European listing place for a growth-based company," says Archinard (Nat. Biotechnol. 21, 719, 2003). This was the dream of former Nasdaq Europe (Brussels), which went bust in June 2003 (Nat. Biotechnol. 21, 840, 2003), and Archinard says although the "timing was not right, the need is still there." Part of the solution may come from another new

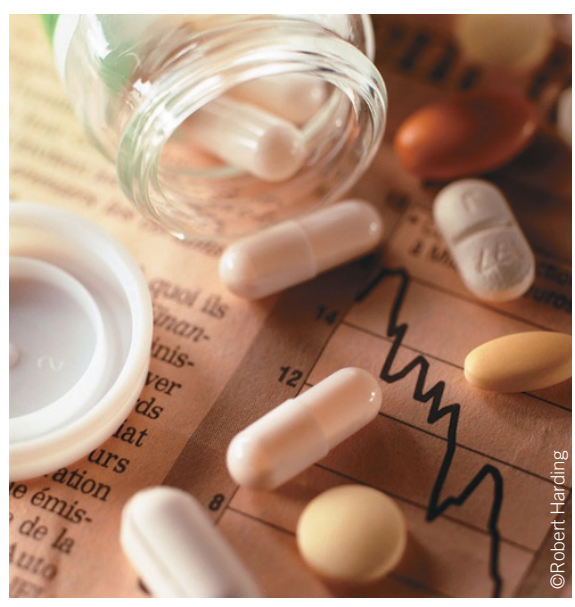

European biotech companies welcome new harmonization measures, but still need a panEuropean listing place.

directive, called the Investment Services Directive (ISD), which would subject all trading partners, whether they are exchanges trading listed shares or banks trading off-market shares, to a single legal regulatory framework common across Europe (Nat. Biotechnol. 21, 1262, 2003).

"If the idea [of ISD] catches [on], and if there is a real competition between banks and exchanges, this could create market opportunities for small and medium enterprises," says Gregor Pozniak, deputy secretary general of the Federation of European Security Exchanges (Brussels). Presumably, markets would need to create attractive conditions that would enable companies to stand out from competitors. Harmonization could also decrease the cost of raising capital incurred by running multiple exchanges in the fragmented European equity market, according to UK bankers.

Therefore, harmonization of financial market regulations may be able to create a rational environment that will increase investors' confidence in biotech companies. But "the current problems of European biotech companies in particular is the fact that the European publicly listed companies are significantly lower in valuation than the US biotechs," says Heinrich. He echoes many European venture capitalists who believe the only way to accelerate the maturation of the European biotech industry is through consolidation (Bioentrepreneur 20 March 2003, DOI:10.1038/bioent724).

And although the transparency directive will give more pan-European visibility to biotech trading, "it cannot change the attitude of European investors. Either European investors need to open to biotech or investors will have to come from the US," says an insider from the London Stock Exchange. The introduction of an International Accounting Standard, already in place in countries such as Germany, but not everywhere in Europe, will help investors carry out comparisons not only between European and US shares but also across Europe. Yet, European success stories are needed to show investors the potential of biotechnology and eventually bring a remedy to their parochial attitudes.

Sabine Louët, London

\section{US bioethics committee weighs in}

Although issues concerning biotechnology have been off the radar during much of President Bush's nearly three years in office, two major federal reports-one on bioethics, the other on commercial developments and opportunities-were made public in October. Both are broad in scope but far apart in terms of their policy implications, leaving industry observers to wonder how the administration will use the respective information.

The 342-page report from the President's Council on Bioethics (Washington, DC, USA), "Beyond Therapy, Biotechnology and the Pursuit of Happiness," provides a stead- fastly precautionary analysis of prospects for using biotechnology to enhance personal health and performance. The council, which is chaired by Leon Kass of the University of Chicago and the think tank American Enterprise Institute (Washington, DC, USA), devoted 22 public sessions during the past two years to the development of this report.

Meanwhile, a 170-page report from the Department of Commerce (Washington, DC, USA), "A Survey of the Use of Biotechnology in U.S. Industry," delivers an unmistakably upbeat message about the economic impact of biotechnology, declaring 